\title{
Research автіcle: Yield gap analysis in Cassava and strategies to improve the production in Tamil Nadu, India
}

\section{A. Janaki Rani}

Article Chronicle: Received :

23.10.2017;

Revised :

17.12.2017;

Accepted :

03.01 .2018

\section{KeY Words :}

Cassava, Yield gap,

Production

technologies,

Constraints,

Strategies
SUMMARY : Cassava is an industrial cum commercial crop of Tamil Nadu, India mainly processed for starch and sago. Among 32 districts of Tamil Nadu, Salem district stands first in area, production and productivity. In recent years, the area under Cassava is under threat and the production is not sufficient to meet the industrial demands. Keeping this in view, the study focuses on the various factors responsible for the area shrinkage and yield gap prevailing for major Cassava varieties and intended to develop strategies. The results revealed that majority of the farmers $(63.33 \%)$ facing a yield gap of 16 to 30 per cent. For different varieties of Cassava the average yield gap is 5.86 t/ac. Introduction of short duration crops like sunflower and maize, Mosaic virus and tuber rot, unavailability of quality planting materials, lack of awareness on improved technologies were the major factors for yield loss. In order to increase the yield/ac awareness has to be given to adopt the recommended technologies and popularization through various extension methods is the need of the hour.

How to cite this article : Rani, A. Janaki (2018). Yield gap analysis in Cassava and strategies to improve the production in Tamil Nadu, India. Agric. Update, 13(1): 48-53; DOI : 10.15740/HAS/AU/13.1/48-53.

\section{Author for correspondence :}

\section{A. Janaki Rani} Department of Human Development, Home Science College and Research Institute (TNAU), Madurai (T.N.) India

Email:janakimurugan8@ gmail.com 